\title{
Sex selection migrates to Canada
}

$\mathrm{E}$ asy access to abortion and advances in prenatal sex determination have combined to make Canada a haven for parents who would terminate female fetuses in favour of having sons, despite overwhelming censure of the practice, economists and bioethics experts say.

Arguing that Canadian lawmakers' silence on the issue is undermining the status of women, they're calling for federal legislation to uphold societal and professional values opposing sexselective abortion, either through a direct ban or restrictions on the disclosure of fetal gender. They also contend that sex-selective abortion is forcing physicians to compromise between their ethical obligations to discourage sex selection and legal obligations to respect their patients' autonomy.

"It really works against everything we believe in Canada in terms of equality. It works against our Charter [of Rights and Freedoms]," says Kerry Bowman, a bioethicist at the University of Toronto's Joint Centre for Bioethics in Ontario. "At very least, it would be fair to ask why a couple wants to know the gender of their child ... because that in itself is not directly linked to the health or well-being of the child, except in rare cases of sex-linked diseases or disorders."

Sex-selective abortion has historically been considered an Asian phenomenon - a perfect storm of ancient prejudice, poverty and, in cases such as China's one child policy, flawed population control, explains Lena Edlund, an associate professor of economics at Columbia University in New York City, New York. "We don't expect immigrants, let alone their children, to continue doing it once they've settled in North America."

But Kevin Milligan, an associate professor of economics at the University of British Columbia in Vancouver, notes that recent analyses of census data for areas with large South and East Asian immigrant populations reveal

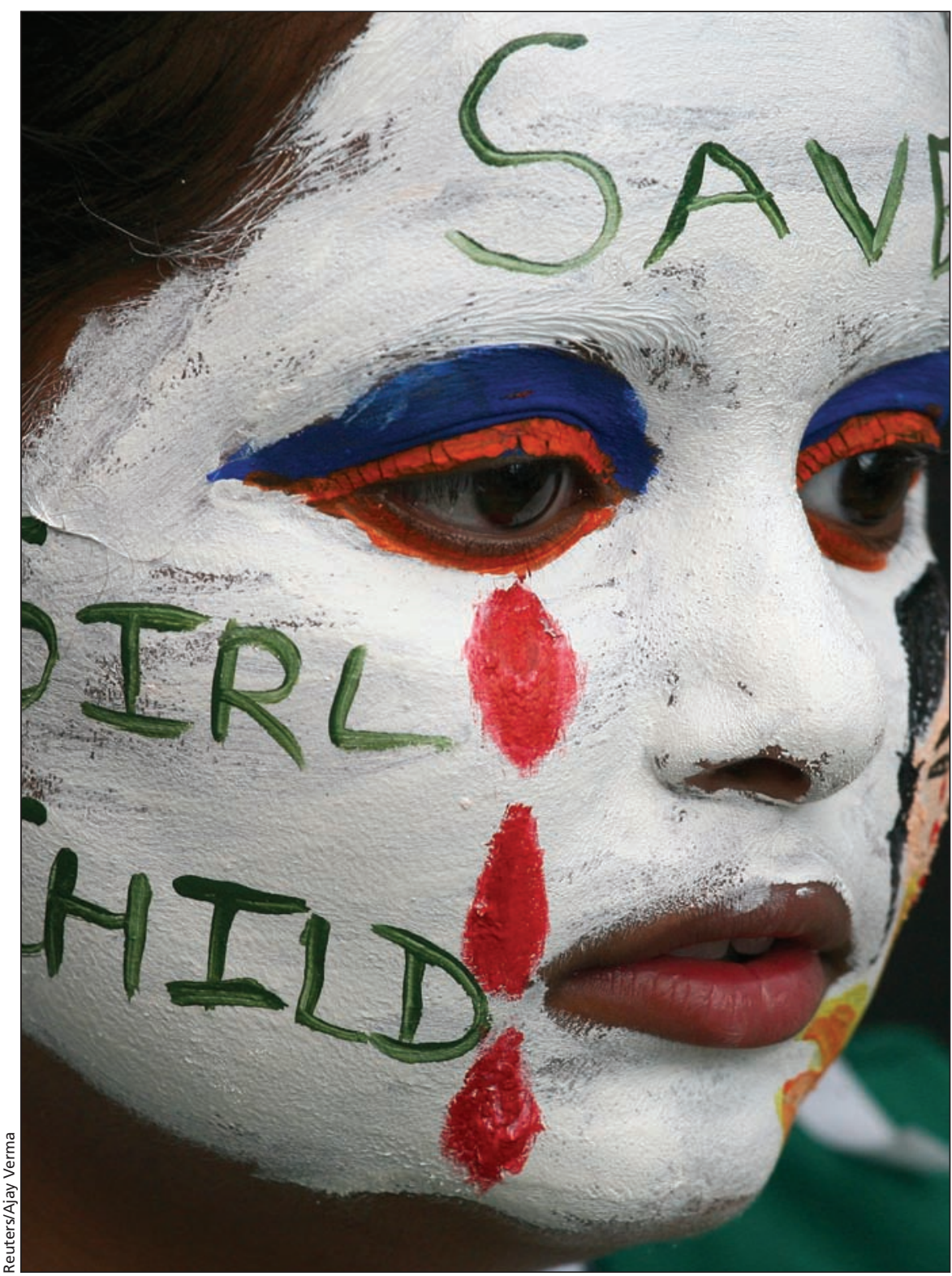

A girl with her face painted with an awareness message on female feticide participates in a face-painting competition in the city of Chandigarh, India.

unnaturally high rates of male birth, "consistent with what is observed back in Asia," and provide "strong evidence" that immigrant families continue to sex select despite improved socioeconomic prospects.

The natural ratio of males-tofemales at birth is already slightly male-biased at 1.05 , or 105 males to every 100 females. Though the sex ratio for first births among first generation South and East Asian immigrants to Canada is only slightly higher than the norm at about 1.08 , the ratios become increasingly skewed for each subsequent birth where all previous children are female. For example, the sex ratio for third births to Chinese, Korean and Vietnamese immigrants who already have two daughters is 
1.39. For Indians, that ratio is $1.90-$ almost two boys born for every girl, according to a working paper prepared for the United States National Bureau of Economic Research (www.aeaweb.org /aea/2011conference/program/retrieve .php?pdfid=48).

Most Canadians have long regarded sex-selective abortion as odious. As early as 1993, a Royal Commission on New Reproductive Technologies survey indicated that $92 \%$ are against the practice (www.sogc.org/jogc/abstracts/full /201001_HealthPolicy_1.pdf).

But a variety of factors, including the affordability and ease of access for both abortion and sex determination services, as well as Canada's deep-rooted respect for diversity, have enabled sex-selective abortion to "take on a life of its own and persist" in spite of public condemnation, Edlund says.

Ottawa banned the sex selection of implanted embryos among women undergoing in vitro fertilization when Parliament passed the Assisted Human Reproduction Act in 2004, but the law doesn't protect the resultant fetus from subsequent termination on the basis of gender (http://laws-lois.justice.gc.ca /eng/acts/A-13.4/).

That "devalues all women" and sends the message that protecting unborn females is "somehow secondary" to the sacred cow of choice, argues Gwen Landolt, national vice president of REAL Women of Canada, an Ottawa, Ontario-based women's organization. It also ignores the fact that many women are "bullied to produce males" and have little choice in the decision to sex select.

But feminist and pro-choice organizations are loathe to admit any restriction on a woman's right to abortion on request and argue the answer to sex- selective abortion is raising the status of women through broad social change over the long-term.

"Being pro-choice means supporting a woman's right to decide whether or not to continue a pregnancy for whatever reason, even if one personally does not agree with her reason," the Abortion Rights Coalition of Canada stated in a position paper (www.arcc-cdac.ca/postion papers/24-Sex-Selection-Abortions.pdf). "If a woman is in a dependent and vulnerable position within her family, where she feels obligated to abort a female fetus ... the woman's health and life are the primary concerns ... which can mean ensuring she has access to a safe abortion."

Moreover, there's nothing to prevent a woman from lying about her reason for requesting an abortion once she's learned the sex of the fetus, says Bowman.

A better option may be to restrict the disclosure of the sex of a fetus until it's past the gestational age at which an elective abortion is possible, he explains.

The College of Physicians and Surgeons of British Columbia has recommended against fetal gender determination for nonmedical purposes on the grounds that sex-selective abortion is "socially repugnant, and it is unethical for physicians to facilitate such action" (www.cpsbc.ca/files/u6/Fetal -Sex-Determination.pdf).

But such nonbinding professional directives against fetal gender determination for the purposes of sex selection provide little practical guidance to physicians on how to navigate the ethical and legal morass of discouraging sex-selective abortion while avoiding litigation and respecting a woman's right to her own medical information (www.sogc.org/jogc/abstracts/full/2010 01_HealthPolicy_1.pdf).
Adherence to such directives varies widely as a consequence, even in provinces where disclosure is less common, such as BC, Milligan says.

Some physicians are uncomfortable wagging a finger at their patients' cultural practices, explains Bowman. "We're given very strong messages in Canada that we need to be as respectful to people's cultural differences as possible, and the risk with trying very hard to accommodate those differences is that we can overlook something that's largely unethical."

The advent of home tests that can determine fetal gender within seven weeks of conception means that a "truly determined person" can learn the sex of their fetus without visiting a doctor or too much inconvenience, Milligan says.

As such tests become more advanced, they exacerbate the ethical dilemma, particularly if they're used to determine other fetal characteristics, Bowman adds. "What we're seeing with sex-selective abortion is the tip of the iceberg ... We really have to think about our values as a society as technology evolves. If we stand back and say these are autonomous choices, we could get to a place where we're highly selective about the kinds of people we want as children and the kinds of people we feel should be born." Lauren Vogel, CMAJ

CMAJ 2012. DOI:10.1503/cmaj.109-4091

First of a two-part series.

Part 2: Sex-selective abortions: no simple solution

(www.cmaj.ca/lookup/doi/10.1503 /cmaj.109-4097). 